DOI: $10.18524 / 2519-2523.2020 .15 .218687$

УДК 94(477)

\title{
WHAT HISTORY SHOULD CHILDREN IN 5TH CLASS LEARN: TO THE PROBLEM OF UKRAINIAN PROPEDEUTICS
}

\author{
Taras Chukhlib \\ ORCID: https://orcid.org/0000-0002-2604-4816) \\ DSc (History), Professor \\ Institute of history of Ukraine, NAS of Ukraine \\ 4, Hrushevskoho Str., Kyiv, 01001, Ukraine \\ taras_chuhlib@ukr.net
}

[Review of the publication "Concept and programs of teaching the history of Ukraine at school" (project). Materials of IV and V Workshops on monitoring of school textbooks of Ukraine ":" Program of teaching the history of Ukraine in school. 5th class: "Introduction to History" (author N. Yakovenko). - K., Stylos Publishing House, 2009].

Тарас Чухліб

ORCID: https://orcid.org/0000-0002-2604-4816 Доктор історичний наук, провідний науковий співробітник Інституту історії України НАН України Вул. Грушевського, 4, Київ, 01001, Україна taras_chuhlib@ukr.net

\section{ЯКУ ІСТОРІЮ ПОВИННІ ВЧИТИ ДІТИ У 5-МУ КЛАСІ: ДО ПРОБЛЕМИ УКРАЇНСЬКОЇ ПРОПЕДЕВТИКИ}

[Рецензія на видання "Концеепція та програми викладання історії Украӥни в школі (проект). Матеріали IV та V Робочих нарад з моніторингу шкільних підручників Украӥни»: «Програма викладання історії Украӥни в иколі. 5-й клас: «Вступ до історї̈» (автор Н. Яковенко). - К., Видавничий дім «Стилос», 2009].

Зазначимо, що один із авторів видання «Концепція та програми викладання історії Україні в школі (проект). Матеріали IV та V Робочих нарад з моніторингу шкільних підручників України» професор Наталія Яковенко здійснила велику евристичну роботу щодо вивчення змісту більшості шкільних підручників з історії України, а також спробу продукування нових програм з історії України для вітчизняних шкіл. Запропонована Н. Яковенко «Концепція викладання історії України в школі» (далі - Концепція), на нашу думку, не зовсім відповідає засадам шкільної історичної освіти. Адже у ній простежуються положення, які можуть бути піддані сумніву.

Насамперед, дискусійними є пропоновані у завданнях Концепції тлумачення відносно того, що «історія - це відкритий процес, який не визначають наперед жодні закони» (адже світова історіографія, філософія, культурологія тощо продовують полемізувати щодо цього визначення), а учні повинні «розуміти різницю між 
історичною подією та її інтерпретацією» (с.8). І це зробити досить важко, адже по суті все те, що ми розуміємо під «історичною подією і $\epsilon$ «інтерпретацією», а різні «історичні школи» користуючись своєю методологією можуть по-різному оцінювати ту чи іншу подію.

Досить важко, на нашу думку, буде запровадити i т. зв. аксіологічну компетентність серед учнів, що передбачає «уміння формулювати оцінку історичних подій та історичних постатей, суголосну до цінностей та уявлень відповідного часу чи відповідної групи людей». 3 огляду на це викликає сумнів впровадження серед принципів історичної освіти т. зв. загальнонаукового підходу, який передбачає «ознайомлення учнів із достовірними фактами та їх інтерпретаціями 3 метою формування цілісного наукового світогляду» (с. 9). Зауважимо, що «цілісного наукового світогляду», з огляду на різні причини (головною серед яких є багатолітня відірваність вітчизняної науки від світового історіографічного процесу), на сьогодні не має не тільки переважна більшість шкільних вчителів та університетських викладачів історії, але й істориків-науковців.

Позитивним є бажання автора Концепції впровадити принцип антропологізації («олюднення») історії України, що передбачає постання в уяві учня «пластичного образу минулого в усій його різноспрямованій динаміці» (с. 10). При цьому антропологічний підхід, який «ставить в центр уваги людину», має дозволити бачити «конкретні прояви буття суспільства», що базуються на «прикладах поведінки конкретних соціальних груп» (с. 11). Також автор декларує відхід від «ідеологічно» сконструйованого минулого на користь його «реального» конструювання. Такий методологічний підхід, на іiі думку, має передбачати відмову від викладання вітчизняної історії як «ексклюзивної історії українців» на користь висвітлення історії «заселеної без перерви території», а отже поряд з антропологічним пропонується т. зв. територіальний (на відміну від «народницького/націєтворчого» та «державницького») підхід до осягнення минулого України. А чому б, наприклад, не поєднати ці три базові наукові принципи у висвітленні нашої історії?

Серед основних завдань Концепції є i методична прив'язка викладу історії України до паралельного курсу всесвітньої історії. Хоча зрозуміле бажання авторів щодо «вписування» історії України до всесвітньої історії, на нашу думку, мусить відбуватися не лише через «європеїзацію» («історія України точилася на тлі європейських процесів», с. 11 і т. ін.), але й бачення того, що українське минуле від давніх часів і до кінця XVIII ст. в усіх своїх проявах було тісно пов'язане не тільки з Свропою, але й зі Сходом (Азією, Степом, Орієнтом, Османами, Кримом), а потім - Росією (Євразією). А отже нав'язування відвертого «європоцентризму» у вітчизняному шкільному курсі $\epsilon$ неприпустимим, адже таким чином викривлюється не лише історична пам'ять учнів, а й наперед програмується ідеологічна конструкція щодо історико-культурного зверхництва Заходу як такого i, відповідно, меншовартості України як території чи держави та українців як етносу чи політичної/громадянської нації.

На прикладі пропедевтичної Програми викладання історії України в школі для 5-го власу («Вступ до історії») спробуємо довести, що пропоновані для застосування у ній методологічні принципи «антропологізації», «територіалізації» та «європоцентризму» (які на сьогодні є визнаними історичною наукою) з одного боку, лише використовуються задля механічної екстраполяції на шкільний курс історії України певних в т. ч. і «застарілих» ідеологем, а 3 іншого - тільки декларуються 3 метою впровадження суб'єктивного/авторського (в даному випадку - Н. Яковенко) бачення українського минулого. Перед тим зазначимо, що програми викладання історії в школі не повинні ототожнювати 
завдання «чистої» історичної науки з метою шкільної освіти, а особливо ії пропедевтичних предметів. Перенесення підходів, характерних для написання академічних праць чи навіть вузівських підручників до шкільних програм призводить до невмотивованої переобтяженості, недоступності, нецікавості, а звідси - низької педагогічної ефективності цих самих програм.

Серед основних критичних зауважень до Програми для 5-го класу «Вступ до історії» насамперед виокремлюються наступні.

По-перше, у ній переважає надмірна «академічність» викладу, щуо заважатиме сприймати відповідний матеріал дітьми 10- та 11-річного віку:

- приклад № 1: на уроці «Історія в географічних назвах» (Тема I) пропонується пояснення слова «топоніміка» в межах оповіді про «Локальні топонімічні легенди» (с.16). Можливо учень і запам'ятає що означають грецькі слова «місце» та «ім'я», але водночас вчителеві треба ще додатково пояснити значення слова «локальний»;

- приклад № 2: на уроці «Становлення Нової Свропи» (Тема III) передбачається вивчати «Релігійну полеміку й війни між протестантами й католиками» (с. 18). При цьому пропонується пояснити що таке «Реформація», але ж потрібно ще роз'яснити поняття «релігійна полеміка», «протестанти» і «католики» і т. ін.;

А загалом 10- та 11-річні учні протягом досить короткого шкільного курсу мають взнати про: «етимологію понять» (!?), «християнізацію іменувань» (!?), «антропонімію класу» (!?), «колективне життя», «варварські королівства», «виокремлення аристократів» (с. 16); «рицарський кодекс поведінки», «язичницьке многобожжя», «монотеїстичні релігії» (!?), «моральні цінності», «вдосконалення ремесла», «офіційну документацію», «обрядові свята» (с. 17); «культурну специфіку», «обіг інформації», «безпомильність Церкви» (!?), «міське самоврядування», «етнічну строкатість», «міський простір», «зміст новацій» (с.18); «здешевлення книжки», «розширення козацьких прав», «професійне військо», «суспільство та владу Української козацької держави» (с. 19); «Велику Французьку революцію як початок «Нової Свропи» (!?), «природнє середовище і густоту заселення», «нові погляди на націю», «національні змагання бездержавних народів». «розповсюдження поглядів на демократію» (с. 20); «прискорений розвиток промисловості», «примусову колективізацію», «винищення інтелігенції», «комуністичні перетворення», «нацистську окупацію» (с. 21) тощо. Очевидно, що такий «науковий академізм»у викладі $\epsilon$ неприйнятним та надзвичайно складним для вікових особливостей п’ятикласників.

По-друге, у Програмі передбачається викладення великого за обсягом матеріалу, його інформаційне, а відтак - змістове перевантаження:

- приклад № 1: на уроці «Мешканці давньої і середньовічної Європи» (Тема II) на с. 16 пропонується розкрити аж 12 (!) навчальних проблем: 1) «Середземномор'я як колиска європейської цивілізації»; 2) «Оповідь про греків і римлян»; 2) «Варварська» Європа за межами римської держави»; 3) «Об’єднання племен як перша форма організованого колективного життя»; 4) «Переміщення [об'єднань племен] по Свропі»; 5) «[Переміщення об'єднань племен] по Україні; 6) «Кельти»; 7) «Германці»; 8) «Слов’яни»; 9) «Велике переселення народів»; 10) «Терени розселення слов'ян»; 11) «Територія середньовічної України як історична батьківщина українського етносу»; 12) «[Територія середньовічної України як історична батьківщина] кримсько-татарського етносу».

При цьому маленьким дітям пропонується не лише засвоїти надзвичайно складний за сприйняттям і великий за обсягом історичний матеріал (а чи кожний 
вчитель може його подати у такому стислому викладі?), але й обов'язково запам'ятати, що таке «цивілізація», «варвар» та «етнос» (графа «Пояснення понять...»). Поза увагою автора програми залишається розкриття таких важливих понять, як «Європа», «римська держава» та «народи», чого учні ще не знають 3 огляду на виклад попередніх тем. Викликає зауваження й модернізаційне та певною мірою маніпулятивне положення щодо синхронізації історичної появи на території середньовічної України власне українського та кримсько-татарського етносів.

- приклад № 2: на уроці «Друга світова війна» (Тема V) на с. 21 передбачається вивчити вже 13 (!) питань: 1) «Прихід до влади нацистів у Німеччині»; 2) «Початок і перебіг Другої світової війни в Свропі»; 3) «[Початок і перебіг Другої світової війни] в СРСР»; 4) «Трагедія Голокосту»; 5) «Нацистська окупація України»; 6) «Примусове вивезення молоді на роботи до Німеччини»; 7) «Рух Опору нацистам: європейські партизани; 8) «[Рух Опору нацистам]: радянські партизани»; 9) «Визвольний український рух проти нацистів»; 10) «[Визвольний український рух проти] Радянського Союзу»; 11) «Українська повстанська армія»; 12) «Втрати українців у війні»; 13) «Внесок [українців] у перемогу над нацистами». Кожна з цих важливих історичних проблем $є$ надзвичайно серйозною з огляду на їхню постійну актуалізацію та політизацію, а тому передбачається, що вчитель у стислому режимі лише обмежиться короткою характеристикою, що неодмінно призведе до певної чи надмірної ідеологізації.

Окрім названих, великою інформативністю переобтяжені такі уроки: «Вступ» (пропоновано 10 питань для вивчення), «Відлік часу в історії» (12 питань), «Зміни у віруваннях» (10), «Винаходи й здобутки цивілізації» (11) та «Повсякденне життя людини європейського Середньовіччя» (12 питань протягом одного уроку).

По-третє, у Програмі присутня однобічність трактувань, які є авторськими $і$ в окремих випадках дуже суб' єктивними та ідеологічно заангажованими. Це ускладнює для педагога виклад матеріалу, а для учня - його сприйняття та засвоєння:

- приклад № 1: під час уроку 1-го теми II розглядається питання «Об’єднання племен як першої форми організованого колективного життя». Тут відразу ж у вчителя мають виникнути логічні питання: а можливо першою формою $є$ все ж таки об'єднання людей в «плем'я»? а може перед «племенем» були ще й інші організаційні форми? а чому ми маємо навчати дітей тільки в межах теорій Чарльза Дарвіна чи Фрідриха Енгельса і т. ін.;

- приклад № 2: під час уроку 6-го теми III розглядається питання «Стисла оповідь про козацькі повстання за розширення своїх прав». Тут не враховується та обставина, що між «козацькими повстаннями» 1591 - 1593 рр. та 1637 - 1638 рр. (хронологічна відстань майже 45 років!) відбулася значна еволюція поглядів їхніх керівників: від ідеї захисту козацьких «прав і привілеїв» до ідеї «оборони віри» українського/руського народу. Віра, в даному випадку православна, на той час була невід'ємною частиною етнічної або ж ранньонаціональної самоідентифікації більшої частини українців, а тому повстання 1625, 1630 й, особливо, 1637 - 1638 рр. можна маркувати не лише як «козацькі», але й «українські». Отже, козаки боролися не лише за «розширення своїх прав» (до речі, яких - соціальних, економічних чи може політичних?), але і від початку 17 ст. захищали право на православне віросповідання тогочасного українського етносу Корони Польської та Великого князівства Литовського.

Окрім вищеназваних у Програмі присутні й інші однобічні трактування, зокрема такі, як: 
1) «Становлення украӥнського козацтва як професійного війська: илях від Запорозькой Січі до реєстрового Війська Запорозького» (с. 19). Нагадаємо, що реєстрове українське (бо були ще суто й польські підрозділи козаків) козацьке військо у межах 1568 -1638 рр. нараховувало від 300 до 3000 осіб. Разом 3 тим, загальна чисельність нереєстрового (а, отже, «непрофесійного» за логікою автора) Війська Запорозького коливалася на середину 1630-х pp. у межах від 40 до 60000 тисяч вояків. Чому про нього немає жодної згадки? I чому маніпулятивно в учнів має створюватися враження, що козацтво творилося лише як професійне військо (що автоматично передбачає впливи на нього лише державної влади Корони Польської)? Видається, що це лише частина істини. Інша ж складова процесу одержавлення козацтва, «станова» та «політична», чомусь замовчується. Та і загалом дітям не роз'яснюється, що ж таке Запорозька Січ і на якій основі вона виникла.

2) «Причини й перебіг козацького повстання [Богдана Хмельницького]» (с. 19). Сьогодні стосовно цієї події в українській історіографії переважно вживаються означення «Національно-визвольна війна», «Визвольна війна», «Українська національна революція», «Козацька революція» та ін., але майже ніхто не маркує їі як «козацьке повстання». Адже поняття «козацьке» в даному випадку значно звужує сприйняття учнями 5-го класу справді революційних подій середини 17 ст. Яким був етнічний склад повсталого козацтва? Які претензії (а серед них були не лише «станові» вимоги) вони висували до владних структур Корони Польської? Якими були причини чергового «повстання» і чим воно відрізнялося від попередніх? Висвітлення цих важливих питань дасть змогу зрозуміти, чому в 1648 р. «професійне військо» (за версією Н. Яковенко) на чолі з Б. Хмельницьким (до речі у тексті Програми навіть не згадується про те, що він був гетьманом Війська Запорозького) задумало повстати.

3) «Демократія як найкращий устрій держави і суспільства» (с. 20). В межах «європейського», а також «османського» та «китайського» світів (адже автор прагне до «увсесвітнення» шкільного курсу історіі) були й інші політико-філософські погляди на «демократію», які не визнавали ії за «найкращий устрій».

4) «Поява перших політичних партій, які ставили за мету зміну існуючого державного устрою революиійним шляхом» (стор. 20). Даний вислів автора дуже вже нагадує положення сумнозвісного «Короткого курсу ВКП (б)» авторства Й. Сталіна, який потім «плавно» перекочував в усі вузівські підручники «Історії КПРС». А чому $б$ не подати матеріал про «нереволюційні» партії? Чи таких не було? Чи в даному випадку детермінується російська революція 1917 року?

5) «Фізичне знищення інтелігенції, незгідної з комуністичними перетвореннями» (c. 21). Сприймається так: «комуністичні перетворення» були позитивними (перед тим йшлося про «розвиток промисловості», хоча якими загалом були ці «перетворення» не розкривається), а хто їх не сприймав, того «справедливо» карали! А чи мала ця інтелігенція «антропологічне обличчя»? Якою були ії «територіалізація» та етнічний склад? А чи не можна запропонувати вчителеві розповісти про повсякденне життя «гепеушника-енкаведиста», який «фізично знищував» якихось абстрактних (за поданням автора Програми) інтелігентів? Останніх лише знищували, тобто вбивали, чи висилали на Соловки, або ж до Сибіру? Чи усіх освітян, вчених, акторів, медиків, інженерів і т. д. репресували чи були й такі, що прислуговувалися або ж вірно й переконано служили режиму? Це питання чомусь замовчується;

6) «Примусове вивезення молоді на роботи до Німеччини» (с. 21). Так до Німеччини більшість молоді справді вивозили примусово, але також був певний 
добровільний рух. Якщо у Програмі декларується антропологічний підхід, то чому б не розповісти дітям про конретну особу (це можна зробити на основі ії спогадів, а отже використати інструментарій «усної історії»), яку примусово вивезли, але яка, наприклад, закохалася у свого господаря-німця, а потім навіть і одружилася 3 ним. Скільки було таких випадків? I чому близько 200000 «остарбайтерів» після 1945 р. залишилося на Заході? Це явище було особливим чи типовим? Чи не сприяв би такий приклад формуванню у дітей основ толерантності та політкоректності?;

7) «Визвольний украӥнський рух проти нацистів та Радянського Союзу» (с. 21). Якщо вже подано «нацисти», то 3 іншого боку мусять бути «комуністи» або «більшовики», а у випадку вживання назви «Радянський Союз», відповідно «Німеччина». А загалом у Другій світовій війні на боці гітлерівської Німеччини воювали не лише нацисти, тобто представники Націонал-Соціалістичної робітничої партії Німеччини, але й представники інших партій та безпартійні.

Не зрозуміло також, чому шкільні програми для 5 - 12 класів є «Програмами викладання історії України в школі», а Програма для 5-го класу є «Вступом до історї̈», а не до «історії України» (стор. 3, 15). Очевидно саме тому на українську історію 335 годин відводиться всього близько 16 годин, тобто менше половини від усього матеріалу!

Тепер щодо гучних заяв автора про «антропологізацію» програми «в центрі якої має бути людина»: протягом 35 уроків п’ятикласник має узнати лише про 17 (!) історичних осіб, а саме - «першого українського лікаря Агапіта», «князів Володимира Святославовича, Ярослава Мудрого і Данила Галицького» (ліхтарик) «книговидавця Івана Федорова» (ліхтарик), «Мартіна Лютера» (ліхтарик), «Юрія Дрогобича» (ліхтарик), «Гійома де Боплана» (ліхтарик), «князя Дмитра Байди-Вишневецького», «Богдана Хмельницького», «Івана Мазепу» (ліхтарик), «Шевченка» (ліхтарик), Шашкевича (ліхтарик), «Михайла Грушевського, Павла Скоропадського, Симона Петлюру (ліхтарик), «Михайла Горбачова» (ліхтарик). При цьому три особи не є представниками суто української історії, а про 14 осіб учні мають взнати не з основного матеріалу, а з текстів додаткових «ліхтариків».

Знову присутні одні «великі» і «видатні» - князі, гетьмани і президенти. Хоча, як бачимо, далеко не всі. А де ж представники «мовчазної більшості», де вихідці із декларованих у Концепції «конкретних соціальних груп» (стор. 11) - «дрібного шляхетства», «рядового козацтва», «заможнього селянства», «цехового міщанства» і т. ін. Де, врешті-решт жінки? Ні княгині Ольги, ні Анни Ярославни, ні Ганни Золотаренко, ні Олени Виговської, ні Ганни Скоропадської, ні Лесі Українки, ні Ліни Костенко? Але це знову ж таки «великі», а де «середні» та «менші» жінки?

Порівняємо такий підхід із відкинутою та розкритикованою пані Н. Яковенко попередньою і діючою сьогодні Програмою Міністерства освіти і науки України від 2005 р. (вид-тво «Перун»). Тут у межах тих самих 35 годин вчителі та учні можуть ознайомитися 3 діяльністю 16 осіб: Володимира, Ярослава Мудрого, Володимира Мономаха, Данила Романовича, Василя-Костянтина Острозького, Петра Конашевича-Сагайдачного, Богдана Хмельницького, Івана Мазепи, Павла Полуботка, Петра Калнишевського, Григорія Сковороди, Івана Котляревського, Тараса Шевченка, Івана Франка, Лесі Українки та Михайла Грушевського. Як бачимо, «антропологічні ряди» двох програм за окремими винятками майже нічим не відрізняються. То в чому полягає новаторство п. Н. Яковенко?

Основною метою «антропологізації» за задумкою автора $\epsilon$ відмова від надмірної мілітаризації, а також «обговорення політичних та військових подій здебільшого на прикладах поведінки конкретних соціальних груп», «оповіді про розмаїття поведінкових мотивацій різних політичних, соціальних чи локальних груп» (с. 11). I справді, з 35 годин лише 4 години безпосередньо відводяться військовій історії, при цьому дві години 
відводяться на «козацьку добу» XVI - середини XVII століття і дві години на 20 століття (Першу та Другу світові війни). Як діяв конкретний «антропологічний індивід» або ж конктертна «політична, соціальна чи локальна група» в межах Першої світової війни 1914 1918 pp., можна побачити 3 розпису відповідного уроку, що передбачає: «Виникнення великих держсв у Першій світовій війні. Труднощчі війни й наростання незадоволення діями правителів та урядів у краӥнах-учасницях війни. Революиії в Європі 1917 - 1918 років. Завершення війни, розпад Австрійської та Російської імперій $і$ поява на ӥхніх територіях нових держсав» (виділ. - Рец.). А тепер запитаємо автора Програми: чи знає вона хоча б одного рядового українця (а таких було десятки тисяч) - героя Першої світової війни, який був нагороджений російським царем чи австро-угорським імператором? Чи були серед генералітету та офіцерів тієї чи іншої воюючої армії вихідці 3 «підросійської» чи «підавстрійської» України? Чи представник якоїсь певної конкретної групи (наприклад, російського офіцерства або ж рядового складу) родом з Чернігівщини або Полтавщини відправляв листи до рідних і що він у них писав про війну та їі лихоліття? А скільки представників українського етносу/нації чи інших етносів, які населяли територію України (як військового так і «мирного») загинуло під час Першої Світової війни? I цього немає серед передбачуваних питань даного уроку. А як же тоді задекларовані у Концепції принципи висвітлення «лихоліття та фізичних й матеріальних втрат мирного населення»? На жаль, у Програмі майже не бачимо ні Людини як такої, ні наскрізної «повсякденної історії», ні «усної історії». А що ж є? Як бачимо, тільки голослівні «концептуальні» твердження та пропозиція викладати ту ж саму «владну історію», тобто минуле «держави/країни/імперії» та «правителів/урядів» як абстрактних політичних і владних сил.

«Людина є центром історії» (за Люсєном Февром). Погоджуємося, що для багатьох представників історичної науки це визначення може бути основоположним методологічним гаслом. Однак як таку антропологічну «аксіому» застосовувати в шкільній освіті? Адже дітям треба пояснити, що людську істоту все ж таки створив Бог. А як бути з тим, що люди об’єднуються в соціальні/антисоціальні групи, а також стани, етноси, нації тощо? А ці групи, стани, етноси, нації у свою чергу складають суспільство, займаються політикою, воюють між собою, організовують владні інституції, творять держави та ін.? Тоді у підлітка може виникнути закономірне питання: а хто ж тоді стоїть в «центрі історії» - Бог, Людина/Люди, Стан/и, Етнос/и, Нація/і, Військо/а, Суспільство/а, Влада/и, Держава/и? Очевидно що у даному випадку не потрібно відмовлятися від «теологічної», «національної», «соціальної», «владної» (або ж «політично-мілітарної» за визначенням Н. Яковенко) історій на користь лише «людиноцентричної» версії минулого. Найкращий вихід завжди простий поєднати усі ці визнані у світовій історіографії й дидактиці методологічні принципи осягнення минулого.

Тепер щодо декларованої у пропонованій Концепції «територіалізації», головним завданням якої є заміна видуманої самим же автором міфічної «політично-мілітарної історії» (адепти якої начебто творили попередні шкільні програми та підручники: див. с. 10 Концепції) на користь історії «етнічного багатоманіття» та «представлення історичної специфіки окремих регіонів України».

Запитаємо, що учні 5-го класу можуть взнати про пращурів сучасних росіян, білорусів, євреїв (згадано двічі: урок № 4, тема II; урок № 4 теми V), поляків, кримських татар (один раз: урок № 1, тема II), німців, молдаван, болгар, угорців, румунів, греків, вірменів (один раз: урок № 4, тема II), циган (ромів), грузин (один раз: урок № 4, тема II), гагаузів, татар, караїмів, ногайців, чехів, словаків, кримчаків, сербів та інші етноси, які населяли у різний час такі етнічні землі України як Запорожжя, Слобожанщина, Чернігово-Сіверщина, Новоросія, Кубань, Лівобережжя, Правобережжя та Західна Україна загалом, Галиччина, 
Поділля, Буковина, Волинь, Полісся, Закарпаття, Крим (Таврія), Холмщина, Підляшшя, Перемишльчина, Мармарощина, Берестейщина, Задунайщина, Буджак та ін.? Про переважну більшість із них (як ентосів, так і земель) немає жодної згадки або ж навіть натяку впродовж усіх 35 уроків. Лише під час одного (!?) уроку (урок № 1 теми IV) вчителеві пропонується розповісти дітям знову ж таки про якісь абстрактні «багато етносів», що входили до Австрійської, Російської та Османської імперій (с. 20). I знову «імперії», а де ж «регіони», «землі», «краї»? Ось так п. Н. Яковенко впроваджує собою ж задекларований територіальний принцип викладу матеріалу, тобто майже зовсім його не застосовує на практиці.

Викликає зауваження й запропонований принцип «соціального розчленування» історії України на «представлення суспільства як конгломерату груп» (а де ж поділася Людина?) й особливо запровадження такого підходу в $5-8$-х класах, адже в такому випадку учню пропонується вибирати: бути «своїм», «зрадником» чи «колаборантом»? Якщо у старших класах підліток/юнак можливо й зможе вибрати, хто був «правий» чи «винний» серед його пращурів, то у 10 - 14-річному віці дитина ще не може усвідомити на основі пропонованого «критичного аналізу» (?!) свого вибору.

Сьогодні фахівці з методики викладання історії наголошують на таких основних вимогах до програм з історії: 1) урахування часу, місця й педагогічної доцільності запровадження історичного поняття (дати, факту), виходячи зі структури історичного матеріалу, що вивчається, та вікових особливостей учнів; 2) логічне впорядкування у тексті підручника фактів і понять 3 урахуванням набутих учнями знань, умінь i навичок та програмового матеріалу, який вивчатиметься далі; 3) неодмінне пояснення нових і складних понять; 4) побудова методичного апарату таким чином, щоб учень отримував не готові рішення проблемних завдань, а спонукався до їх самостійного (під керівництвом учителя) пошуку; 6) яскравість викладу матеріалу, оскільки саме цей компонент часто слугує мотивацією до вивчення вітчизняної історії $[1$, с. 129 130]. На переконання більшості вчених-педагогів, для 5-го класу необхідно розкривати матеріал в емоційно-насичених образах та робити подачу матеріалу у вигляді Оповідей або ж Книги для Читання. Натомість п. Н. Яковенко, на наше глибоке переконання, пропонує педагогам викладати дітям скорочений та спрощений вузівський (!?) курс «Вступу до історії».

Історичні знання, отримані учнями 5-го класу, мають узагальнювати пропедевтичний (упроваджувальний) курс історії, специфіка якого за висновками педагогів та методистів полягає, по-перше, у розв'язанні на доступному для дітей рівні найважливіших проблем, які хвилюють людей (життя, смерть, любов, щастя, справедливість тощо) та розкритті історії більше на «побутовому», ніж на науковому рівні. Психологічні особливості (підвищена емоційність, імпульсивність i, як наслідок, нестійкість уваги), а також несформованість інтересів дають змогу вивчати дітям 10- 11річного віку лише епізодичний, тобто ознайомлювальний чи оглядовий курс історії, де вона подається як ряд хронологічно послідовних епізодів: описів історичних подій, життєписів історичних осіб, “образів” з повсякденного життя людей у минулому тощо. Цього також немає у пропонованій Програмі.

Чому б, наприклад, автору рецензованої Програми не скористатися апробованим методологічним підходом до тематичного розподілу навчального матеріалу для шкільного курсу історії Польщі, який викладається в 4 - 6-х класах початкової школи сусідньої слов'янської держави. Він планомірно розподіляється на такі тематичні блоки: 1) державний герб та державний гімн; 2) патріотичні пісні та патріотична історична література; 3) місцеві осередки національної пам'яті; 4) відомі поляки; 
5) особистість та спільнота; 6) участь школярів в управлінні; 7) самоврядування; 8) індивід, суспільство, нація, держава; 9) громадянські права та обов'язки; 10) норми суспільного життя - спільне благо - патріотизм [2, с. 33]. У зв'язку з цим видається доцільною пропозиція львівського педагога Р. Пастушенка про те, що в українській початковій школі потрібно було б вивчати в основному інформацію «про минуле рідного для дітей краю, населеного пункту (міста, села), подати легенди про місцеві історичні пам'ятки, біографії відомих людей, національних героїв, історію національних свят тощо: легенди, думи, уривки 3 літописів, спогадів та інших документів» [3, с. 103-107].

Натомість п. Н. Яковенко, на нашу думку, лише декларативно оголосила про те, що «український етнос є серцевинним стрижнем національної історії» (с. 10), а сама свідомо чи підсвідомо прагне, по-суті, деукраїнізації (а, отже, своєрідної глобалізації) свідомості майбутніх громадян України, яку й справді впродовж багатьох віків репрезентували й продовжують представляти різні етноси. Проте, принаймі 3 XVIII ст. українці як етнос становили від 75 до 90 \% від усього населення, а багато представників інших етносів/націй не соромилися захищати інтереси України та вважали себе «політичними українцями», які належали до «спільної батьківщини». Згадаймо Пилипа Орлика (чешсько-білоруського походження), Володимира Антоновича (польського), В'ячеслава Липинського (польського), Дмитра Донцова (російськкого), Наталію Полонську-Василенко (російського), Максима Рильського (польського), Миколу Бажана (єврейського), Олену Апанович (білоруського) та багатьох інших видатних i менш знаних особистостей. Адже саме у 5-му класі закладаються основи громадянського патріотизму, поваги до інших націй і держав. А коли власне «українське» (громадянське, політичне, етнічне, національне) у даному випадку намагаються замінити на принцип «етнічного багатоманіття» це виглядає як профанація певних методологічних концепцій та неодмінно веде до космополітичноглобального сприйняття свого минулого.

Хіба так можна виховати патріота Української (!) держави або ж «ідеального» члена громадянського суспільства України, хай то буде українець, росіянин, поляк, єврей, грек чи болгарин за етнічним походженням? У росіян $є$ своя держава, так само як і в поляків, євреїв, греків чи болгар, а програми шкільної освіти цих країн вирізняються надзвичайно великим патріотизмом саме до своєї Краӥни, свого Етносу, своєї Нації, своєї Мови, своєї Культури, своїх Традицій, своїх Символів і врешті-решт своєї Icторії. Та чи висвітлюється в шкільних підручниках Росії (або ж Польщі, Ізраїлю, Греції, Болгарії) внесок українців в історію їхніх держав чи суспільств? Питання, очевидно, поки що залишається риторичним.

Перевантаження навчальною інформацією, що притаманне рецензованій Програмі для 5-го класу, для більшості учнів стане важким та відчуженим у сприйнятті. Причина цього в намаганні автора механічно вмонтувати зміст шкільної історичної освіти до авторських (інколи надто контроверсійних) досягнень в сучасній історичній науці. Однак історія-дидактика, як відомо, $€$ засобом духовного, соціокультурного впливу на особистість, а історія-наука - засобом наукового дослідження минулого. Не кількість історичної інформації повинна стати пріоритетом програми викладання історії України, а засоби ії опрацювання на уроці.

На жаль, потрібно відзначити, що положення рецензованої Концепції історії України в школі (проект) та Програми для 5-го класу «Вступ до історії» (автор Н. Яковенко) не дотримуються повною мірою рекомендацій Ради Європи «Про викладання історії у XXI столітті в Свропі» (ухвалена Комітетом міністрів 31 жовтня 
2001 р. на 771-му засіданні). Звертаємо увагу й на те, що Програма для 5-го класу також не $\epsilon$ синхронізованою з методичними засадами викладання історії в школі та майже не враховує вікових особливостей учнів 10 та 11-річного віку. 3 метою виправлення перерахованих недоліків та зауважень дані авторські проекти потребують подальшого серйозного обговорення та експертної оцінки за участю провідних істориків (як науковців, так і викладачів), педагогів (як вчених, так і практиків), в т. ч. методистів, соціологів, психологів, задля їхньої кардинальної переробки.

Насамперед, нашим учням 5-го класу необхідно викладати історичний матеріал про минуле рідного для дітей краю, населеного пункту, розповідати легенди про місцеві історичні пам'ятки, біографії відомих людей, національних героїв, історію національних свят, вчити українські історичні пісні та думи, а також вивчати історію національної символіки. Виклад пропедевтичного історичного курсу в навчальних закладах України різнього рівня має відбуватися за допомогою спеціальної ігрової педагогічної методики та запровадження «живих уроків» - відвідування музеїв, парків, історичних місць свого міста, селища чи села. Тільки так ми зможемо виховати повноцінного громадянина.

\section{Джерела та література:}

1. Огнев'юк В. До питання про зміст історичної освіти / В. Огнев'юк // Концептуальні засади сучасної шкільної історичної освіти. Збірник документів і наукових праць. - Бердянськ, 2007. 2. Розенбаум С. Національні аспекти в сучасних польських навчальних програмах з історії / C. Розенбаум // Історична освіта: європейський та український досвід. Викладання національної історії в школах Центральної і Східної Свропи. - К., 2010.

3. Пастушенко Р. Концептуальні засади історичної освіти («круглий стіл» на сторінках журналу) / Р. Пастушенко // Історія України. - 1999. - №4. - С. 3-6.

\section{References:}

1. Ohneviuk, V., 2007. Do pytannia pro zmist istorychnoi osvity. Kontseptualni zasady suchasnoi shkilnoi istorychnoi osvity. Zbirnyk dokumentiv i naukovykh prats. Berdiansk. [in Ukrainian]

2. Rozenbaum, S., 2010. Natsionalni aspekty v suchasnykh polskykh navchalnykh prohramakh z istorii. Istorychna osvita: yevropeiskyi ta ukrainskyi dosvid. Vykladannia natsionalnoi istorii $v$ shkolakh Tsentralnoi i Skhidnoi Yevropy. Kyiv. [in Ukrainian]

3. Pastushenko, R., 1999. Kontseptualni zasady istorychnoi osvity («kruhlyi stil» na storinkakh zhurnalu). Istoriia Ukrainy, 4, pp. 3-6. [in Ukrainian]

Отримано: 01.12.2020 p. 